\title{
Afscheidsrede "in itinere"
}

Citation for published version (APA):

Kitslaar, P. J. E. H. M. (2008). Afscheidsrede "in itinere": Oratie door Prof. dr. P.J.E.H.M. Kitslaar. (1 ed.) Universiteit Maastricht. https://doi.org/10.26481/spe.20080101pk

Document status and date:

Published: 01/01/2008

DOI:

10.26481/spe.20080101pk

Document Version:

Publisher's PDF, also known as Version of record

\section{Please check the document version of this publication:}

- A submitted manuscript is the version of the article upon submission and before peer-review. There can be important differences between the submitted version and the official published version of record.

People interested in the research are advised to contact the author for the final version of the publication, or visit the DOI to the publisher's website.

- The final author version and the galley proof are versions of the publication after peer review.

- The final published version features the final layout of the paper including the volume, issue and page numbers.

Link to publication

\footnotetext{
General rights rights.

- You may freely distribute the URL identifying the publication in the public portal. please follow below link for the End User Agreement:

www.umlib.nl/taverne-license

Take down policy

If you believe that this document breaches copyright please contact us at:

repository@maastrichtuniversity.nl

providing details and we will investigate your claim.
}

Copyright and moral rights for the publications made accessible in the public portal are retained by the authors and/or other copyright owners and it is a condition of accessing publications that users recognise and abide by the legal requirements associated with these

- Users may download and print one copy of any publication from the public portal for the purpose of private study or research.

- You may not further distribute the material or use it for any profit-making activity or commercial gain

If the publication is distributed under the terms of Article $25 \mathrm{fa}$ of the Dutch Copyright Act, indicated by the "Taverne" license above, 
oratie

Universiteit Maastricht

Prof dr P.J.E.H.M. Kitslaar

Afscheidsrede "In itinere"
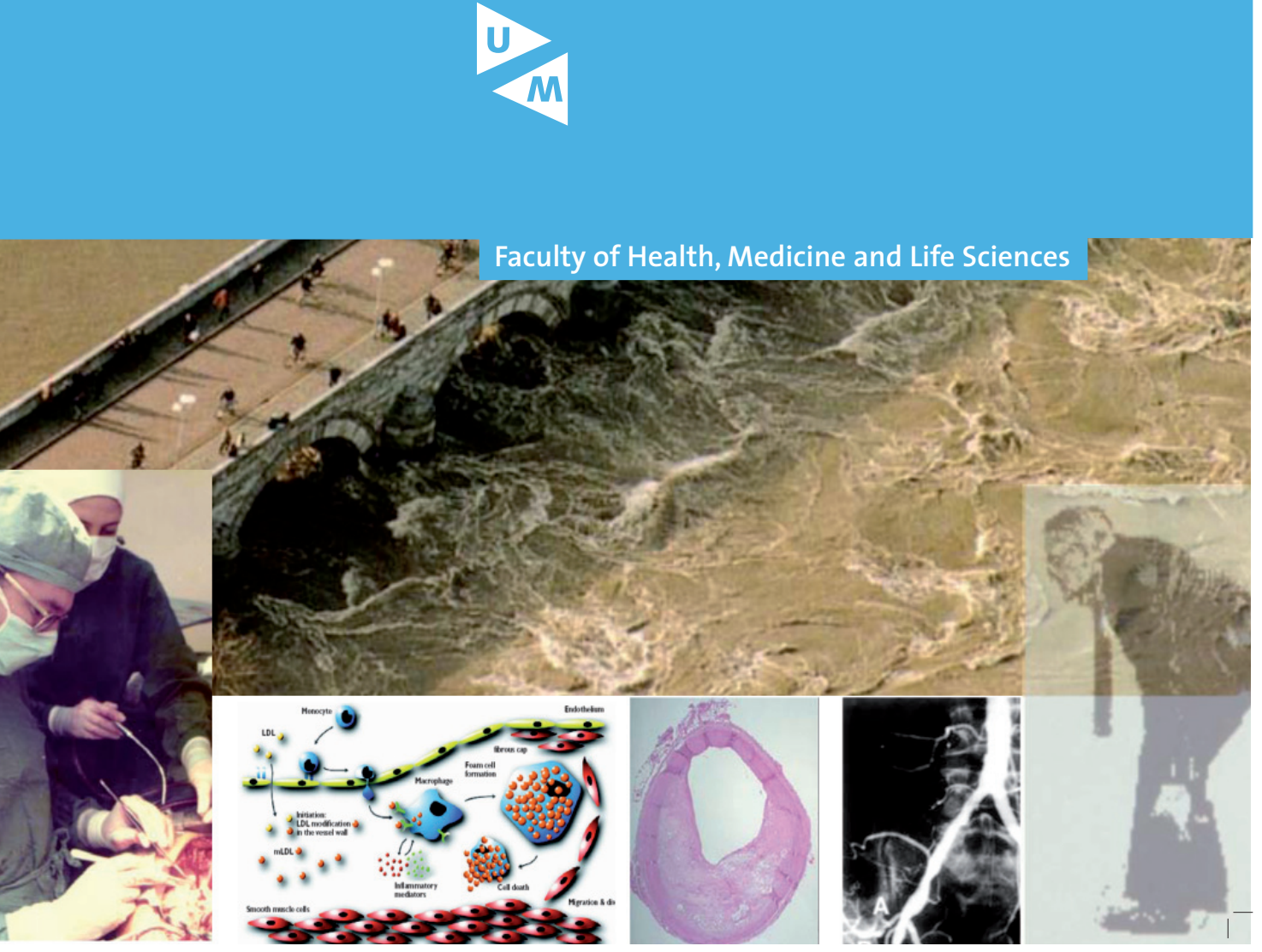

Afscheidsrede "In itinere" 


\section{Colofon}

Ontwerp en print: Océ Business Services, Maastricht

ISBN: 978-90-5681-290-4

NUR: 870

Alle rechten voorbehouden. Niets uit deze uitgave mag worden verveelvoudigd, opgeslagen in een geautomatiseerd gegevensbestand of openbaar gemaakt worden, zonder voorafgaande schriftelijke toestemming van de auteur of uitgever. 


\section{Afscheidsrede "In itinere"}

Door

Prof dr P.J.E.H.M. Kitslaar

Maastricht University 
Mijnheer de Rector Magnificus, geachte collegae, gewaardeerde toehoorders uit universiteit, ziekenhuis, vrienden- en kennissenkring en familie,

Velen van $U$ zullen bekend zijn met werk van onze Nederlandse dichter en schrijver Cees Nooteboom. Hij is veel gelauwerd, onder andere met een Nijmeegs eredoctoraat vanwege zijn totale oeuvre. Toch is hij waarschijnlijk het bekendst vanwege zijn reisverhalen uit vele delen van de wereld. Over Spanje schreef hij meerdere boeken, waaronder "De omweg naar Santiago". Die titel suggereert een reis met een einddoel. Het boek bevat echter impressies kriskras vanuit heel Spanje met zijn lege binnenlanden, zijn daarin verspreide kloosters, kastelen en eeuwenoude steden met herinneringen aan een mohammedaans, joods en christelijke verleden. Naast beschrijvingen uit het moderne Spanje, bevat het boek historische en culturele beschouwingen over uiteenlopende zaken zoals de conquistadores of het sinister katholicisme, belichaamd in 'onze' koning Philips II, en kunstschilders als de Zurbarán en El Greco. Telkenmale laat de schrijver zich van geplande wegen afleiden en geraakt, als bij toeval, op zijpaden van zijpaden die hem op dat moment nog meer boeien dan Santiago de Compostela.

Dit thema van toeval en het afwijken van ogenschijnlijk vaststaande reisroutes drong zich aan mij op toen ik voor deze rede nadacht over mijn loopbaan, mijn vak en mijn leeropdracht. Die werden ook gekenmerkt door toeval en zich op korte termijn voordoende mogelijkheden. Overigens zou ik niet de suggestie willen wekken dat er, behalve dit thema, veel meer overeenkomsten zouden zijn tussen de literaire rijkdom van Nooteboom en datgene waarmee ik $U$ de komende vijftig minuten hoop te boeien.

Ruim twee en twintig jaar werk ik nu als chirurg in het Maastrichtse academischziekenhuis en wanneerikovereen maand die werkzaamheden moet neerleggen ben ik ook nog precies zeventien jaar Hoogleraar vaatchirurgie aan deze Universiteit geweest. Dit deel van mijn in totaal dertigjarige chirurgische loopbaan berustte niet op een tevoren bedacht plan, maar was het gevolg van toeval dat op mijn weg kwam.

De universitaire wereld was voor mij, bij mijn aanstelling, vrijwel terra incognita. Afgezien van mijn opleiding tot arts, was ik geheel perifeer, dat wil volgens ons spraakgebruik zeggen in een niet-academisch ziekenhuis, opgeleid. Alleen voor de patiëntenzorg had ik dus adequate training gehad, de overige voor academisch werk benodigde vaardigheden heb ik me, net als velen hier, in de praktijk eigen moeten maken. 
Met plezier heb ik gemanoeuvreerd binnen het academisch ziekenhuis, vanaf de tijd dat het nog een provinciaals stadsziekenhuis was tot nu toe, nu het door zijn omvang ruimtelijke en organisatorische problemen kent.

Bijmijnaantredenalshoogleraarhadiknatuurlijktoekomstverwachtingen over mijn vakgebied en mijn bijdrage daaraan. Die zal ik, samen met ervaringen en resultaten uit mijn loopbaan gebruiken voor deze rede, opgebouwd rond vier thema's: dertig jaarvaatchiru rgie, hoogleraarschap, perifeer versus academisch chirurg en liefhebberijen.

\section{0 jaar vaatchirurgie. Wat bleef, wat verscheen, wat verdween?}

Dertig jaar geleden was ik in de laatste jaren van mijn opleiding tot algemeen chirurg, een fase waarin een aankomend chirurg toen nog volop met de vaatchirurgie in aanraking kwam. Ik kan daardoor nu terugkijken op ruim dertigjaar nauwe betrokkenheid bij de vaatchirurgie. In die periode zijn er geheel nieuwe aspecten aan toegevoegd. De toen al bestaande componenten van de vaatchirurgie waren overigens ook nog vrij jong. Wat we tegenwoordig vaatchirurgie noemen, ontstond pas in het midden van de afgelopen eeuw en bestaat dus nu net zestig jaar. Over de laatste dertig jaren ben ik dus in staat een ooggetuigenverslag te geven. Maar eerst presenteer ik $U$ een stukje oudere historie.

Eeuwenlang bestond de enige chirurgische handeling aan bloedvaten eruit ze dicht te schroeien of met kokende olie te begieten om bloedingen te stoppen. Dank zij de Franse militair chirurg Ambroise Paré werd die barbaarse methode in de $16^{\mathrm{e}}$ eeuw weer vervangen door het tijdens de middeleeuwen in vergetelheid geraakte afbinden van bloedvaten. De echte, reconstructieve vaatchirurgie ontstond pas in het begin van de twintigste eeuw met het werk van de briljante Franse experimenteel chirurg, Alexis Carrell. Tegen het einde van zijn leven verloor Carrell zijn glans vanwege zijn rol bij de eugenetische plannen van de Vichy regering in bezet Frankrijk en hij zou als nazi-collaborateur zijn berecht, als hij niet op tijd was overleden. In 1912 was daarvan nog geen sprake en ontving Carrell de Nobelprijs voor Fysiologie of Geneeskunde vanwege zijn in Amerika verrichte werk op het gebied van vaatnaden en orgaantransplantatie.

Hierna werd het tot aan de tweede wereldoorlog stil rondom chiru rgische ingrepen aan de bloedvaten

De voor de vaatchirurgie belangrijkste noviteit uit het interbellum 
was de Translumbale Aortografie of TLA. Dit röntgenonderzoek, in 1929 door de Portugese chirurg Reinaldo Dos Santos ontwikkeld, maakte het mogelijk de slagaders in de buik en de benen af te beelden. De TLA werd vervolgens weinig toegepast en speelde pas na de vijftiger jaren een rol van betekenis in de kliniek, een rol die vervolgens nu ook al weer meer dan twintig jaren is uitgespeeld.

De klinische beoefening van reconstructieve vaatchirurgie is pas echt begonnen in de USA tijdens de tweede wereldoorlog, om na die oorlog aan beide zijden van de Atlantische oceaan een geweldige spurt te maken. Hierbij ging de oude wereld, nog herstellend van zijn oorlogsschade, weer gelijk op met Amerika. In de eerste tien naoorlogse jaren werden vrijwel alle operaties en vaatvervangende materialen ontwikkeld, die tegenwoordig in hun essentie nog steeds in gebruik zijn.

Een chronologische opsomming van de hoogtepunten uit de relatief recente geschiedenis van de vaatchirurgie ziet er als volgt uit:

In de jaren 1944/45 werden in de USA de eerste succesvolle operaties aan de grote slagaders verricht bij kinderen met aangeboren hart- en aorta afwijkingen.

In 1946 nam de Portugese chirurg Jean Cid Dos Santos, zoon van de uitvinder van de TLA, bij het verwijderen van een bloedstolsel uit een beenslagader per ongeluk ook een deel van de binnenlaag van die arterie mee. Tegen de verwachting in, bleef het bloedvat open, waardoor Dos Santos ertoe kwam die verwijdering van de binnenlaag als nieuw type operatie te doen voor afgesloten bloedvaten, onder de naam endoarteriëctomie (later TromboEndArteriëctomie of TEA genaamd).

In 1948 publiceerde Kunlin uit Parijs de resultaten van een operatie volgens een ander concept. Hij legde naast de afgesloten bovenbeenslagader, die zelf ongemoeid werd gelaten, een omleiding aan met een ader, de zogenaamde veneuze bypass.

Deze bypassoperatie en de endarteriëctomie voor afsluitingen van de beenslagaders zijn enige tijd naast elkaarbeoefend, maar al snel gaven de meeste chirurgen de voorkeur aan de bypass en werd de endarteriëctomie weinig meer toegepast. Deze keuze was niet gebaseerd op enig vergelijkend, laat staan, gerandomiseerd onderzoek.

In 1950 en in 1952 vervingen twee, wederom Franse, chirurgen, Oudot en Dubost, als eersten voor een afsluiting en voor een verwijding van de buikaorta dat vat door homografts, dus aorta's van overledenen.

Tezelfdertijd verving in 1952 Voorhees in de USA voor het eerst een aorta door een kunststof bloedvat. 
Dat toen ontwikkelde type vaatprothesen is nu, vijftig jaar later, nog steeds in gebruik en heeeft daarmee een duurzaamheid en effectiviteit, waarop bijna geen andere medische technologie zich kan beroepen.

Tenslotte voerde in 1953 de Britse chirurg Mr. Eastcott de eerste operatie aan een vernauwde hersenslagader uit.

Ook nog in 1953 meldde de Zweedse radioloog Seldinger een vinding waarmee bloedvaten afgebeeld kunnen worden via een dunne catheter, ingebracht via de liesslagader.

Die naar hem genoemde angiografie betekende een reuzenstap voorwaarts ten opzichte van de Translumbale Aortografie. Die TLA was toch een soort 'Hit-and-run' methode, waarbij de chirurg, als hij de injectienaald eenmaal via de rug in de aorta had ingebracht, nauwelijks nog invloed had op welke bloedvaten zouden worden afgebeeld. Toch bleef de TLA in de meeste Nederlandse ziekenhuizen nog gehandhaafd tot in de zeventiger jaren om toen pas plaats te maken voor de veel betere Seldinger angiografie.

Ik hoop dat dit compacte overzicht $U$ duidelijk heeft gemaakt waarom de vijftiger jaren van de vorige eeuw, toen in korte tijd vrijwel de gehele vaatchirurgie ontstond, wel de gouden periode van de vaatchirurgie worden genoemd.

Hierna volgde een decennium van consolidatie en verspreiding van de verworvenheden uit de gouden jaren naar de praktijk van de grotere ziekenhuizen. Het was de periode waarin vooraanstaande chirurgen een vasculair aandachtsgebied binnen de chirurgie creëerden en hun patiëntenseries opbouwden waarop de eerste vaatchirurgische klinische research kon worden gebaseerd. In Nederland waren deze 'tweede generatie' vaatchirurgen onder anderen Vink te Leiden, van Dongen uit Sittard en later Amsterdam en Vermeulen te Utrecht, de opleiders van de momenteel nog net wel of net niet meer praktiserende oudere vaatchirurgen.

Toen ik, na mijn werk als tropenarts, in de zeventiger jaren aan mijn chirurgische opleiding begon was de vaatchirurgie al een belangrijk onderdeel van de algemene chirurgie. Operaties aan de buik- en halsslagaders en bypassoperaties in het been behoorden tot het chirurgisch standaardpakket.

Gedurende mijn opleidingstijd kwam een lawine aan nieuwigheden op gang die het aspect van de vaatchirurgie ingrijpend zou veranderen en die tot op heden doorgaat. Wel zijn enkele klassieke vaatoperaties gebleven, 
maar ze hebben terrein verloren aan minder ingrijpende behandelingen met even goed resultaat. Zo waren bijvoorbeeld operaties voor verstopte bekkenslagaders tijdens mijn opleiding nog veel voorkomende ingrepen, terwijl die nu vrijwel uit de operatiekamers zijn verdwenen door de opkomst van de Percutane Transluminale Angioplastiek of PTA. Deze behandeling, die bestaat uit het oprekken van een vaatvernauwing met een ballonkatheter en in Nederland meestal Dotteren wordt genoemd, deed zijn intrede in Nederland in de zeventiger jaren, tijdens mijn opleiding. Eerst werd de PTA vooral verricht in de bekkenslagaders, later zijn daar toepassing in andere vaten bijgekomen, waaronder die van het hart.

Ook nog tijdens mijn opleiding veranderde de vasculaire diagnostiek zeer ingrijpend dank zij het Doppler ultrageluidonderzoek, waarmee het mogelijk werd om bij patiënten op niet-invasieve wijze, dus door de intacte huid heen, de bloedstroom in slagaders te analyseren.

Mijn promotieonderzoek toentertijd betrof nog in ontwikkeling zijnde arteriële Doppler testen. Daarmee maakte ik deel uit van een club chirurgen in opleiding die de verschillende niet-invasieve testen van het vaatstelsel in Nederland introduceerden.

Als resultaat hiervan werd in 1977, dus inmiddels 30 jaar geleden, het eerste klinische vaatfunctie laboratorium in Nederland geopend hier in Maastricht, in het toenmalige St Annadal ziekenhuis, de voorloper van het huidige Academisch Ziekenhuis. Vrij snel daarna startten andere chirurgen in hun ziekenhuizen ook functionele vaattesten, zoals Buth in het Catharinaziekenhuis te Eindhoven en Vermeulen, Eikelboom en ikzelf in het St Antoniusziekenhuis te Utrecht, waar we onderzoeken invoerden voor de halsslagaders en het perifere vaatstelsel.

Nogsteedstijdens mijn opleiding wasik ook getuigevandeeersteklinische ervaringen in Nederland met de Computer Tomografie of CT scanning en de Digitale Subtractie Angiografie, afgekort DSA. Deze twee nieuwe röntgen technieken hebben sindsdien de hele klinische diagnostiek en met name ook het vasculaire onderzoek revolutionair veranderd en verbeterd. De Digitale Subtractie Angiografie werd aanvankelijk ingezet om vaatfoto's te maken na injectie van een contrastmiddel in een ader en zou, dacht men, injectie van contrast in de slagaders onnodig maken. De kwaliteit van deze zogenaamd intraveneuze DSA's was echter zo slecht dat wij ten opzichte van de TLA van de regen in de drup raakten. 
De intraveneuze DSA verdween dan ook snel geheel van het toneel, en werd vervangen door de intraarteriële DSA via Seldinger katherisatie, de tegenwoordige standaard angiografie.

Als 'derde generatie' vaatchirurg begon ik mijn werkzaamheden in een grote perifere chirurgenmaatschap te Groningen. Aanvankelijk voerde ik daar toen de vaatoperaties uit die in de twee decennia daarvoor waren ontwikkeld en was mijn diagnostiek gebaseerd op anamnese, lichamelijk onderzoek, simpele Dopplertest en conventionele angiografie

Tijdens de daarop volgende vijfentwintig jaren werd de diagnostiek van bloedvatafwijkingen verrijkt met de Duplex scanning, een combinatie van echografie en high-tech analyse van Dopplersignalen. Daarmee werd het mogelijk zeer precies slagadervernauwingen te karakteriseren en informatie te verkrijgen over karakteristieken van de bloedstroom in venen.

Zeker zo belangrijk voor de diagnostiek van de vaatchirurg waren de latere ontwikkelingen van de Magnetische Resonantie Angiografie, of MRA en de CT angiografie, of CTA. Op de daarmee verkregen afbeeldingen van bloedvaten baseren we nu grotendeels ons chirurgisch beleid. We bevinden ons daarbij nog midden in hun snelle opmars, waarin technici en ingenieurs werken aan steeds geavanceerdere toepassingen.

Ronduit spectaculair was de opkomst en verfijning van een nieuwe operatie voor verwijde aneurysmatische bloedvaten, met name van de aorta. Hierbij wordt via een kleine incisie in de liesslagader een zogenaamde endoprothese ingebracht die zich van binnen uit in het aneurysma vastzet. Hierdoor verdwijnt de bloeddruk op de wand van het aneurysma, dat daarna in principe geen gevaar meer vormt voor de patiënt. Inmiddels gebeurt deze behandeling, die in Nederland voor het eerst in 1994 werd toegepast door Eikelboom en Mali te Utrecht, in vrijwel alle grotere ziekenhuizen, ondanks het feit dat veel technische problemen nog niet zijn overwonnen en we inmiddels geconfronteerd zijn met specifieke complicaties van deze behandeling. Hierdoor bestaat er nog grote controverse over de winst van deze behandeling voor de patiënt, met name op de langere termijn.

Bij vergelijking van de versnelling van de vaatchirurgie in de gouden periode en die tijdens mijn ooggetuige periode, valt op dat degenen die voor die versnelling zorgden in de beide perioden een verschillende achtergrond hadden. In de eerste periode kwam vrijwel alle vernieuwing van chirurgen zelfen waren bijvoorbeeld de eerstevaatprothesen product van huiselijk handwerk van een chirurg. De tweede vernieuwingsgolf, 
met Duplex technieken, CTA, MRA en de endoprothese technologie, is vooral veroorzaakt door fysici, ingenieurs en high-tech industrieën. Deze disciplines en partners zijn dan ook niet meer weg te denken uit de medische praktijk en wetenschap.

\section{Hoogleraarschap}

Toen ik als hoogleraar aantrad heb ik in een oratie uitgesproken wat er in mijn vakgebied zou moeten gebeuren en wat ik daaraan dacht bij te dragen.

De 'derde generatie' vaatchirurgen, mijn generatie zou uiteraard nieuwe methoden van diagnostiek en behandeling blijven ontwikkelen. Daarnaast moest dank zij ons de chirurgische besluitvorming - het 'wikken, wegen en weten' - een solide basis krijgen, liefst ondersteund door gecomputeriseerde medische expertsystemen. Betrouwbare diagnostische testen en kennis van de uitkomsten van behandeling waren hiervoor essentieel. Mijn leeropdracht dacht ik daarom uit te voeren door de betrouwbaarheid van diagnostische testen te onderzoeken en nieuwe testen te ontwikkelen. Om de uitkomsten van onze behandelingen te kennen leek het ons nodig alle behandelingen en hun resultaat prospectief vast te leggen, bij voorkeur in een nationale vaatchirurgische databank, die dan tevens zou kunnen dienen als kwaliteitsinstrument en als basis voor wetenschappelijk onderzoek.

Ik noemde bij mijn aantreden drie concrete terreinen van vaatchirurgisch wetenschappelijk onderzoek van onze groep. Ten eerste ultrageluidanalyses voor de diagnose van vernauwingen in slagaders, ten tweede onderzoek van de microcirculatie, dus de kleinste bloedvaatjes of haarvaten. Als derde researchgebied kozen we de zogenaamde access- of toegangschirurgie. Die omvat het operatief aanleggen van verbindingen van bloedvaten als toegang voor de aan- en afvoer van bloed bij de kunstnierbehandeling. De keuze voor die drie onderzoeksvelden werd allereerst ingegeven door hun belang voor onze patiëntenzorg. Daarnaast door de toenmalige researchlijnen van CARIM, ons facultaire onderzoeksinstituut voor hart- en vaatziekten, waarbuiten het vrijwel onmogelijk zou zijn geweest voldoende partners en structureel geld voor onderzoek te verwerven. Tenslotte werd die keuze ingegeven door de samenstelling van ons chirurgische team, die wordt gedicteerd door de expertise die nodig is voor de patiëntenzorg en nauwelijks door research ideeën. ledere lijn van onderzoek kreeg als trekker een van de toenmalige vaatchirurgen met de relevante expertise, collega Jacobs voor de microcirculatie, collega Tordoir voor de toegangschirurgie en ikzelf voor de ultrageluidonderzoekingen. 
Het is leerzaam om te zien wat er in de praktijk terechtkomt van dergelijke schrijftafel planningen. Had ik bij mijn aantreden al kunnen voorzien dat het merendeel van ons wetenschappelijk onderzoek, zoals ik zal bespreken, heel anders zou uitpakken?

Dan zou ik, dank zij een mij niet gegeven helderziendheid, technologieën en pathologische inzichten moeten hebben kunnen voorspellen die toen nog niet bestonden. Ik som de voor onze latere research relevante, maar toen onvoorspelbare ontwikkelingen op: MRA was nog onbekend, de eerste zogenaamde knock-out muizen, waarvan latere varianten in ons onderzoek een rol zouden gaan spelen, waren pas twee jaar voor mijn aantreden gecreëerd, geheel buiten ons gezichtsveld. In diezelfde tijd was ook de Chlamydia pneumoniae weliswaar als aparte bacterie geïdentificeerd, maar pas jaren later in verband gebracht met atherosclerose, waarop wij er al snel daarna onderzoek mee gingen doen. De publicatie van Russel Ross in het New England Journal of Medicine, die atherosclerose beschreef als ontstekingsreactie, verscheen pas acht jaar na mijn start als hoogleraar. Eveneens pas jaren later ontstond de behandeling van aneurysmata met endoprothesen en daarmee ook de ermee verbonden research, die nu bij ons in handen is van collega Schurink.

Er was dus tijdens mijn chirurgische en academische loopbaan op grote schaal sprake van noviteiten en onvoorziene ontwikkelingen, waarvoor ik onderweg graag mijn oorspronkelijke koers verlegde. Daarvandaan de in het begin opgeroepen analogie met Nooteboom's literatuur en de titel van deze rede, 'In itinere'. Letterlijk betekenen deze Latijnse woorden 'op reis' of 'onderweg'. Ze hebben echter in het spraakgebruik verschillende ruimere, vooral juridische betekenissen gekregen. Toen bijvoorbeeld na de Amerikaanse Burgeroorlog de maatschappelijke positie van net vrijgelaten slaven ter discussie stond, rees de vraag of ze juridisch een 'in itinere' status moesten krijgen vergelijkbaar met die van buitenlanders, zodat ze op reis door verschillende Amerikaanse staten niet in voortdurend levensgevaar zouden zijn. Een dergelijke vrijgeleide om lynching te voorkomen heb ik in mijn loopbaan nooit nodig gehad, dus daar verwijs ik met de titel niet naar. Een modern gebruik van de term vindt men bij internationale subsidies, waarbij een 'in itinere' evaluatie een tussen- of voortgangsrapportage betekent, ter onderscheid van de eindrapportage. 
Naar die betekenis verwijst de titel van mijn rede. Momenteel is er voor mij sprake van een tussenstop waarvan ik er in mijn leven al enkele achter de rug heb en waarvan er waarschijnlijk nog meer in het verschiet liggen. Een goede gelegenheid dus om een tussenbalans te presenteren.

We waren hier steeds met betrekkelijk weinig vaatchirurgen, soms slechts met twee man, meestal gelukkig met zijn vieren. Daarvan was in totaal net geen volle mankracht of FTE voor research geoormerkt. Tijdens mijn hoogleraarschap hebben we daarmee, in de marge van een hectische chirurgische praktijk, een twintigtal geheel of mede aan mij gekoppelde promoties weten af te ronden, terwijl er nog enkele in de pijplijn zitten. Een deel daarvan is te danken aan de specifieke research van Tordoir, die zelf nog steeds ten onrechte het 'ius promovendi' ontbeert.

De inhoud en de resultaten van onze research zou ik het samenvattend motto 'Van vaatwand tot vaatpatiënt' kunnen geven naar de titel van een van mijn colleges voor medische studenten. Net als dat college ging onze research vooral over hoe de bloedstroom de vaatwand beïnvloedt en viceversa hoe afwijkingen van die vaatwand de bloedstroom verstoren en klachten veroorzaken die iemand tot vaatpatiënt maken. We verrichtten daarbij onderzoek met een bereik van molecuul tot patiënt, zowel in het laboratorium als in de kliniek, ofwel van 'bench to bed'.

Met behulp van Duplexanalyses onderzochten we de kenmerken van de bloedstroomsnelheid om vernauwingen in verschillende slagaders op te sporen. Immers, zoals stroomversnelling of turbulentie in een rivier duidt op een plaatselijke engte of ondiepte, zo wijst ook een abrupte toename van de stroomsnelheid in een bloedvat op een vernauwing, bijvoorbeeld door slagaderverkalking. Vooral de moeilijk toegankelijke bekkenslagaders hadden onze aandacht. We verfijnden de Duplex criteria voor vernauwingen in die slagaders en konden aantonen dat voor hun diagnose, de tot dan toe gebruikelijke, angiografie en bloedige drukmetingen niet meer nodig waren, een voordeel zowel voor de patiënt als voor de chirurg. In dezelfde lijn lag ook onderzoek naar Duplex criteria om vast te stellen of zich in een beenbypass een vernauwing ontwikkelt. Een daarop gebaseerde controle van de bypass leidde tot vroegtijdige opsporing van vernauwingen en adequaat ingrijpen waarmee kon worden voorkomen dat de bypass zijn functie zou verliezen. 
Dus die controle loonde de kosten en de moeite en is sindsdien in de vaatchirurgische praktijk dan ook standaard.

In andere onderzoeken keken we naar het effect dat de erlangs schuivende bloedstroom heeft op de wand van slagaders, bypasses en dialysefistels. We bestudeerden hoe de telkens wisselende schuifkrachten, in het Engels 'shear' genoemd, de diameter van de bloedvaten doen veranderen en afwijkingen, zoals intimahyperplasie kunnen teweegbrengen. Intimahyperplasie is een nog steeds niet volledig begrepen proces van verdikking van de binnenwand van een ader of slagader. De afwijking kan leiden tot afsluiting van het bloedvat en ontstaat op plaatsen waar vaatnaden zijn aangelegd, is gedotterd of stents zijn geplaatst in bloedvaten, zoals in de kransslagaders van het hart, of in bypasses of dialysefistels. De aandoening verknoeit daarmee een deel van de ingrepen die chirurgen, cardiologen of interventieradiologen in het vaatstelsel doen. Wij vonden dat de intimahyperplasie die op chirurgische vaatnaden ontstaat vooral wordt veroorzaakt door de daar optredende shear krachten en veranderingen in bloedstroom, zoals omkering van de stroomrichting nabij de vaatnaad. Dit suggereerde, dat aanpassing van de geometrie of vorm van de vaatnaad mogelijk intimahyperplasie zou kunnen voorkomen. In een vervolgonderzoek verricht aan dialysefistels bleek dat echter niet op te gaan, zodat we daarvoor onze operatietechniek niet hoefden te veranderen.

$\mathrm{Bij}$ al deze studies gebruikten we geavanceerde ultrageluid- en analyseapparatuur die door collega Hoeks op zijn afdeling biofysica was ontwikkeld. Voor het welslagen van onze studies was niet alleen die apparatuur, maar bovenal ook collega Hoek's grote kennis van de hemodynamica essentieel.

In de negentiger jaren werd duidelijk dat slagaderverkalking een ontstekingsproces van de vaatwand is, dat mogelijk zelfs door een bacteriële infectie zou ontstaan of verergeren. Net als anderen richtten wij toen ons onderzoek op deze hypothese. Als die klopte konden antibiotica wellicht betekenis krijgen in de strijd tegen atherosclerose. We deden hiervoor parallel aan elkaar twee gelijksoortige onderzoeken zowel in vaatpatiënten als in zogenaamde knock-out muizen. Bij die muizen kan, door kunstmatig aangebrachte genetische afwijkingen, atherosclerose ontstaan, waardoor ze kunnen dienen als surrogaat patiënten, waarin we onze hypothesen sneller en diepgaander kunnen testen dan in echte patiënten. In de muizenproeven veroorzaakte infectie met de Chlamydia pneumoniae bacterie inderdaad uitgebreider 
atherosclerose dan in controledieren. Dit proces kon enigszins worden geremd met antibiotica. In de patiënten vonden we een associatie tussen eerder doorgemaakte Chlamydia pneumoniae infecties en het vaker optreden van vaatproblemen, zoals hartinfarcten en een grotere noodzaak tot operaties aan de bloedvaten. We konden echter met een korte antibioticakuur dit soort complicaties niet voorkomen. Ook was de voortschrijding van de slagaderverkalking er niet mee tegen te houden. Daarmee verviel de hoop om met een simpele antibioticakuur een gevoelige slag toe te kunnen brengen aan atherosclerose, nog steeds de belangrijkste oorzaak van overlijden in de Westerse wereld. Uiteraard gebeurden al deze onderzoeken samen met collega Bruggeman van de afdeling medische microbiologie.

Toen de MRA aan haar opmars begon, testten we met de radiologen de waarde van MRA voor diagnostiek en beleidsbepaling bij patiënten met perifeer vaatlijden en bij dialysepatiënten. We vonden daarbij dat de MRA uitermate geschikt is voor het onderzoek van die chirurgische patiënten en goede beslissingen over operatieve behandelingen mogelijk maakt. Steeds meer verovert de MRA daarom tegenwoordig terrein op het gebied dat tot recent werd ingenomen door DSA en het vaatfunctie laboratorium, overigens zonder een van beide voorlopig overbodig te maken.

Heel dit op zichzelf al boeiende onderzoekslandschap werd verrijkt met enkele, los van de CARIM matrix staande, promotieonderzoeken naar het beleid bij infecties van kunststof bloedvaten in de aorta, naar resultaten van toegangschirurgie en naar de behandeling van spataders. Verder werkten we samen met huisartsen om de rol van Doppler testen in de huisartspraktijk te onderzoeken. Mede op basis daarvan hebben die testen ook in de huisartspraktijk hun intrede gedaan. Tenslotte bouwden we vanuit onze vaatoperaties jarenlang mee aan een grote weefselbank van vaatwandmateriaal, waarmee binnen CARIM zeer lonend fundamenteel wetenschappelijk onderzoek naar atherosclerose werd en wordt gedaan.

$U$ hoorde nog niets over ons geplande microcirculatie onderzoek. We hebben dat aanvankelijk inderdaad enige tijd gedaan met een, academisch gezien, goed resultaat. Echter al snel hebben we afgezien van verdere inspanningen op dat gebied, omdat het te weinig praktische waarde had voor onze patiëntenzorg. 
Over mijn wensen en plannen ten aanzien van de vaatchirurgische databank en de inzet van medische expertsystemen kan ik kort zijn. De vaatregistratie is er nog steeds niet en er is weinig zicht op realisatie ervan op korte termijn. Vele vaatchirurgen hebben zich er voor ingezet individueel uit liefhebberij of vanuit de Nederlandse Vereniging voor Vaatchirurgie, ook in de tijd dat ik er voorzitter van was. Alle inspanningen waren echter tevergeefs. De opzet mislukte, niet door een gebrek aan goede wil, maar door een onrealistische kijk op de ermee gepaard gaande kosten. Na een eerste opzet in veel ziekenhuizen, gesubsidieerd door de Nederlandse Hartstichting, bleek vervolgens niemand de registratie verder te willen financieren. Ik kom hier zodadelijk nog even op terug.

De toepassing van medische expertsystemen ter ondersteunen van artsen bij hun diagnostiek of therapiekeuze, is wereldwijd nauwelijks iets geworden. Ik geloof ook niet meer dat een arts er in zijn spreekkamer echt behoefte aan heeft. Ik heb het dan niet over relatief simpele ICT toepassingen, die bijvoorbeeld alarmeren als een verkeerde combinatie van medicijnen wordt voorgeschreven, maar dat vind ik geen echte expertsystemen.

\section{Perifeer en academisch chirurg}

Als volledig perifeer opgeleid en aanvankelijk ook perifeer werkzaam vaatchirurg, die pas later in zijn loopbaan een koerswending richting academia maakte, wil ik kort bij het thema perifere versus academisch chirurg stilstaan.

Alle chirurgen worden tegenwoordig voor een ongeveer gelijk gedeelte academisch en 'perifeer' opgeleid, anders dan mijn generatie die nog geheel academisch dan wel geheel perifeer werd getraind. Dat leidde toen tot een, eventueel nog wel positief te duiden, eigen 'esprit de corps', maar daarnaast ook tot een blikvernauwing en zelfs wederzijds dédain voor elkaars chirurgische inzichten dan wel vaardigheden. Gelukkig zijn de jongere chirurgen daar tegenwoordig door hun opleiding van gevrijwaard en hebben ze een realistischer kijk op beide typen praktijken. Bovendien zijn ze nu beter toegerust om onderling samen te werken dan de vroegere, wat elitair gevormde macho's.

Nog steeds vormt de dagelijkse recht-toe-recht-aan patiëntenzorg de hoofdmoot van de dagtaak van perifere chirurgen, zeker in de nietopleidingsklinieken, die iets meer dan de helft van alle Nederland ziekenhuizen uitmaken. Daarin verschillen ze van academische 
chirurgen, die naast de patiëntenzorg structureel taken hebben in wetenschappelijk onderzoek en onderwijs aan medische studenten. Inmiddels hebben echter ook de perifere medische specialisten een overhead van niet-patiëntgebonden activiteiten opgedrongen gekregen of vrijwillig op zich genomen. Ook voor hen worden managementtaken en participatie in medisch onderwijs steeds gewoner.

Een aantal perifere specialisten zorgt daarenboven ook nog voor een behoorlijke wetenschappelijke productie. Om deze stelling enigszins te onderbouwen hebikeenseen aaneengesloten reeks klinischeNederlandse vaatchirurgische proefschriften van 1985 tot nu toe geanalyseerd. Een proefschrift werd als vaatchirurgisch geclassificeerd wanneer minstens een van de ermee verbonden promotores een vaatchirurg was. Ik telde hoeveel er, qua auteur en onderzochte patiënten, uit academische of uit perifere klinieken afkomstig waren. Van de om en nabij zeventig proefschriften stamde grofweg veertig procent uit perifere en zestig procent uit academische ziekenhuizen. Dus perifere chirurgen zorgen in Nederland voor een aanzienlijke wetenschappelijke productie.

Neemt men de niet-patiëntgebonden werkzaamheden, de onderwijstaken en het wetenschappelijk werk mee in de balans, dan vervaagt het verschil tussen academische chirurgen en collegae in de perifere ziekenhuizen, zeker voor degenen die werken in een van de zogenaamde Samenwerkende Topklinische Ziekenhuizen in Nederland. Wat er aan verschil overblijft is de verhouding waarin de verschillende typen werkzaamheden worden uitgevoerd en is dus meer gradueel dan essentieel. Perifere chirurgen hebben weliswaar vrijwel geen toegang tot fundamentele research, vanwege de systematiek van de financiering en bemanning van dit type onderzoek, maar behandelen vaak wel weer grotere aantallen patiënten en verrichten meer operaties dan academische chirurgen. Dat laatste is voor klinische research van voordeel, een voordeel waar wij in onze researchprojecten regelmatig dankbaar gebruik van hebben gemaakt door die samen te doen met chirurgen uit de nabije ziekenhuizen te Heerlen en Sittard.

Alles in ogenschouw nemend, acht ik het mogelijk en belangrijk om structurele samenwerking tot stand te laten komen tussen academische en perifere chirurgengroepen. Dit zal voordeel opleveren voor de klinische research die gebaat is bij grote patiëntencohorten. Maar ook basaal onderzoek kan er voordeel van hebben door de rol die weefselbanken en de daaruit voortkomende translationele research al spelen en waaraan meer chirurgen dan alleen de academische kunnen bijdragen met patiëntengegevens en weefselmateriaal. 
Ook de mogelijkheid om eens wat meer in elkaars kliniek te werken kan bijdragen aan meer werkvreugde. Bovendien werkt die samenwerking concentratie van complexe diagnostiek en behandelingen, en dan natuurlijk niet alleen richting academie, in de hand tot voordeel van de patiënt. Hier ligt een mooie uitdaging voor diegenen die voort gaan op de route waar ik nu van ga afwijken. En dat liefst onder het spreekwoordelijk motto: beter een goede buur dan een verre, lees buitenlandse, vriend.

\section{Liefhebberijen}

Op de leeftijd die ik nu heb en zeker wanneer pensionering ter sprake komt, wordt men standaard geconfronteerd met enkele weerkerende vragen en opmerkingen. Veel mensen informeren enigszins bezorgd of je ook hobby's hebt, waarschijnlijk bang dat je kandidaat bent om in het beruchte zwarte gat na het pensioen te vallen. En men wenst je toe nu echt van het leven en hobby's te gaan genieten. Ook de meeste patiënten waarvan ik de laatste maanden vanwege mijn vertrek afscheid nam reageerden zo. Eerst vroeg ik me af of ik zo'n vreugdeloze indruk op hen had gemaakt, terwijl ik zelf dacht plezier in mijn werk uit te stralen. Later bedacht ik dat die reactie vergelijkbaar is met het 'How are you today, sir' in een Amerikaans hotel of winkel, waarop je ook niet wordt verondersteld in te gaan met Europese ontboezemingen. Dus leer je vriendelijk te bedanken en niet meer. Het geeft wel aan dat veel mensen werk en plezierige bezigheden duidelijk van elkaar scheiden. Ik denk echter dat het verstandig is werk en een liefhebberij met elkaar te verbinden.

Als jong arts kreeg ik tijdens de Nationale Tropencursus een levensles, die ik hier graag doorgeef. De Utrechtse hoogleraar Haspels gaf ons, naast waardevolle lessen in tropische verloskunde, tevens het advies er binnen het beroep een professionele liefhebberij op na te houden, zowel om je te onderscheiden van je collegae maar ook als probaat middel om langdurig plezier in je werk te houden. Hij heeft dit zelf tot op hoge leeftijd in praktijk gebracht.

Later kwam ik een vergelijkbaar advies nog eens tegen, toen met de concrete suggestie om je werk in getallen weer te geven, want "Een chirurg die niet telt, telt niet". Mutatis mutandis geldt dat natuurlijk voor alle praktiserende artsen.

Of het dank zij die adviezen was of er anders ook wel in had gezeten weet ik niet, maar mijn loopbaan lang heb ik mijn gewone werk 
verrijkt met activiteiten waar ik extra plezier aan beleefde of een extra uitdaging in zag. Al vóór het tijdperk van de Personal Computer hield ik op een homecomputertje (wie kent ze nog de BBC of Atari machines?) gegevens bij over mijn operaties en hun uitkomst. Na mijn komst naar Maastricht was een van mijn eerste activiteiten het opzetten van een computer registratie van al onze onderzoeken in het vaatlaboratorium en alle operatieve verrichtingen, een simpele vaatregistratie en basis van mijn eerste klinische research in Maastricht. Weer later kwam daar de complicatieregistratie voor de vakgroep chirurgie bij. Tenslotte werd ik recent, weer als bij toeval, betrokken bij het opzetten van het nieuw Ziekenhuis Informatie Systeem van ons Academisch Ziekenhuis. Aan dat laatste heb ik voor de komende jaren een nieuwe baan in het ziekenhuis overgehouden en zo wordt dus een liefhebberij weer werk en sla ik opnieuw een onvoorziene en ongeplande weg in.

Het in maat en getal kunnen uitdrukken van onze professionele activiteiten, inclusief hun gewenste en ongewenste resultaten en uitkomsten, is inmiddels een terechte eis van de maatschappij geworden. Het zal ook snel een kwestie van overleven worden nu openbare ranglijsten van ziekenhuizen en specialisten in zwang raken, of we er nu vrijwillig aan meewerken of niet. De mislukte lancering van de landelijke vaatregistratie leert ons daarbij een les. Het verzamelen en analyseren van de nodige data mag niet afhangen van hobbyisme van enkele medische specialisten, hetgeen in feite de huidige situatie is, maar moet een integraal onderdeel worden van de bedrijfsvoering van ziekenhuizen en medische afdelingen. Dat betekent flinke investeringen in een nieuw type personeel, medische data managers, die hun werk doen zeer dicht tegen de medici aan, omdat die laatsten de belangrijkste bron voor data zullen blijven. Tevens is er een verbetering vereist van de ICT infrastructuur, die in de ziekenhuizen vrijwel overal nog op een bedroevend laag peil is. Dat alles kost veel geld dat nu nog niet in onze organisatiebegrotingen is voorzien. Verbetering van kwaliteit is ook in de gezondheidszorg nu eenmaal niet 'for free' of gratis.

Rond de tijd van mijn komst naar Maastricht drong landelijk het besef door dat het niet meer acceptabel was de blik op een vaatpatiënt te beperken tot hetgeen traditioneel bij een bepaald specialisme hoorde, de kransslagaders van het hart voor de cardioloog, de hersenbloedvaten voor de neuroloog en de bloedvaten in buik of benen voor de vaatchirurg. 
Onze patiënten hebben immers meestal een aandoening van hun gehele vaatstelsel, veroorzaakt door dezelfde ziekte, bijna altijd atherosclerose, waaraan, ongeacht de localisatie, dezelfde risicofactoren ten grondslag liggen, die vragen om een identieke aanpak. Voor de analyse en de aanpak van die risicofactoren verschenen er in Nederland enkele jaren later ook nieuwe spelers op het toneel, de vasculair geneeskundigen, internisten met speciale expertise in vaataandoeningen. Ook werd in die tijd uit dagelijkse waarnemingen in de kliniek steeds duidelijker dat er veel schortte aan de coördinatie en onderlinge samenwerking rondom de patiënt die gelijktijdig bij meerdere vasculaire specialisten onder de aandacht was. Alle reden tot een multidisciplinaire, geïntegreerde kijk op de patiënt, uiteraard met erkenning van de specifieke kennis en expertise van ieder specialisme. Die integrale benadering van cardiovasculaire patiënten werd toen mijn nieuwe professionele liefhebberij en is dat tot heden gebleven. In dat kader richtten we in 1998 in het AZM de werkgroep Vasculaire Geneeskunde op bestaande uit internisten, vaatchirurg, neuroloog, cardioloog, patholoog en interventieradioloog. Het doel was drieledig, verbetering van de logistiek rondom de gezamenlijk patiënten, het creëren van disciplineoverstijgende protocollen en richtlijnen en de inrichting van een gezamenlijke patiëntendatabase om wetenschappelijk onderzoek te faciliteren. Als eerste zetten we onze impressies uit de praktijk om in feitelijke getallen, gebaseerd op een analyse van de logistiek rondom een groep cardiovasculaire patiënten uit ons ziekenhuis. De conclusies daarvan in een rapport uit 2001 waren vergelijkbaar met de bevindingen een jaar later in een rapportage van een veldanalyse uitgevoerd in meerdere ziekenhuizen, waaronder het onze, door de stichting Prismant in opdracht van de Nederlandse Hartstichting. Uit beide rapportages bleek een schrikbarende inefficiëntie in het management van de vaatpatiënten. Trajecten tot enkele maanden lang van eerste presentatie tot afronding van de diagnostische en consultatieve fase waren geen uitzondering. Sommige patiënten kwamen na hun zwerftocht van specialist naar specialist zelfs niet meer terug bij degene die oorspronkelijk begonnen was hun probleem aan te pakken en waren quasi verloren geraakt in onze medisch organisatorische 'flipperkast'. Al deze gegevens brachten de Nederlandse Hartstichting er toe de zorg voor de vaatpatiënt te helpen verbeteren. Dat resulteerde in 2005 in het rapport 'Vat op vaatzorg'. Een van de belangrijkste aanbevelingen daaruit was de vorming van multidisciplinaire teams van vasculaire specialisten in zogenaamde vaatcentra met een herkenbaar 
verantwoordelijk iemand voor zowel de inhoud als de organisatie van het zorgtraject van de individuele patiënt. Dat was nu precies wat inmiddels in ons zieken huis was gestart met de oprichting van het Harten Vaatcentrum. Dit centrum krijgt nu een herkenbaar profiel, trager dan ik me als chirurg wens. Bij dit soort projecten heb je te maken met de kloksnelheid van de betrokkenen, vergelijkbaar met de kloksnelheid van een computer die bepaalt hoe snel taken worden uitgevoerd. Die klok telt bij chirurgen in uren, omdat veel van hun klinische beslissingen niet veel langer uitstel verdragen. Anderen kunnen het af met inwendige klokken op dag-, of zelfs weeksnelheid. De verdere uitbouw van het Harten Vaatcentrum door disciplines met verschillende kloksnelheden en een tegen de achtergrond van een groeiend bureau apparaat, zal ik met belangstelling blijven volgen. Ik zal diegenen, met wie ik er tot nu toe aan werkte, weer tegenkomen bij het ontwerp en de implementatie van het Ziekenhuis Informatie Systeem, dat ook voor het Hart- en Vaatcentrum van levensbelang wordt. Ondanks deze feestelijke uitzwaaidag zijn zij dus nog niet helemaal van mij af. 


\section{Afronding}

Tot slot. De korte beslissing die ik ooit in Groningen nam om te laten geschieden wat is geschied en waardoor ik nu hier sta, heb ik nooit betreurd. Integendeel, ik heb me in het Maastrichtse steeds bijzonder plezierig gevoeld en op mijn plaats. Ik heb volop genoten van de deelname aan de vernieuwingen en aan de routines die horen bij het werk binnen de universiteit en het academisch ziekenhuis, waarbinnen vernieuwing tot de routine behoort. Mijn werkplezier gold in gelijke mate de patiëntenzorg en het management van die zorg, het onderwijs aan medische studenten en chirurgen in opleiding en mijn pogingen wetenschap van enig niveau en relevantie te beoefenen. Dat klinkt bijna als een wat onnozele tevredenheid. Waren er dan geen zaken waarvan ik achteraf spijt heb of had ik geen teleurstellingen te verwerken? Wat het eerste betreft, ja ik heb er enige spijt van dat ik jaren geleden besloten heb mijn onderzoek op het gebied van de veneuze circulatie niet door te zetten. De studie van de veneuze circulatie is immers zeer relevant vanwege de hoge prevalentie van veneuze pathologie en wetenschappelijk uitdagend vanwege de complexiteit van de veneuze circulatie. Ik ben er niet mee door gegaan, omdat ik niet als de professor van de spataders te boek wilde staan. Ook is het vrijwel onmogelijk fondsen te verwerven voor veneus onderzoek. Zelfs CARIM heeft bij zijn laatste reorganisatie alles wat naar venen zweemde, zelfs de toch niet onbelangrijke veneuze trombose, uit zijn programma's weggeschreven. Ook heb ik te vroeg besloten dat het zelf uitvoeren van de endoprothese operaties meer iets was voor de volgende generatie vaatchirurgen, dan voor mijzelf, waarmee ik mezelf enkele jaren uitdagende chirurgie heb ontzegd.

Grote teleurstellingen zijn me bespaard gebleven. Mogelijk dank ik dat aan mijn karakter dat tot ideaal verklaart wat ik op dat moment heb, om me er vervolgens toch weer toe te brengen, iets nieuws te proberen. Mogelijk ook miste ik simpelweg de antenne om machinaties in mijn omgeving op te merken die me, als ze er waren geweest en ik ze had bemerkt, boos, gefrustreerd of ongelukkig hadden kunnen maken. Deze suggestie dat geluk in je leven meer afhangt van je karakter dan van je omgeving doet niets af aan het belang van die omgeving.

Ik prijs me gelukkig hier te hebben kunnen werken binnen een vrijwel steeds harmonische, collegiale en open vakgroep, hetgeen in de academische chirurgische wereld meer uitzondering dan regel is. Ik ben daarvoor de hele vakgroep Heelkunde en in het bijzonder zijn 
achtereenvolgende zeer van elkaar verschillende voorzitters Greep, Kootstra en Jacobs en mijn collegae vaatchirurgen veel dank verschuldigd. Ook de beleidsbepalers binnen CARIM waren mij zeer welgezind, hetgeen mijn research vergemakkelijkte, ook daarvoor dank.

Wie ik hier niet uitvoerig in het openbaar ga bedanken is mijn lieve vrouw Marianne en mijn gezin. Daarvoor vind ik een academische zitting minder geschikt. Wel wil ik hier zeggen dat ik hun lankmoedige en wat stoïcijnse houding ten opzichte van de dominante en storende invloed van mijn werk op hun leven bewonder. Zij hebben zich ontplooid, ogenschijnlijk zonder zich teveel door die verstoringen te hebben laten beïnvloeden. Daarmee hebben ze een onbekommerd plezier in mijn werk mogelijk gemaakt.

Ten slotte dank ik $U$ allen voor uw aanwezigheid en uw aandacht voor hetgeen ik heb gezegd. 

